\title{
1. What is a stabilising anti-corruption reform? Understanding corruption, anti-corruption and fragility
}

Any strategic response to corruption in fragile states will be contingent on how the problem is understood, and the options that are perceived to be available. The aid agencies' definitions and views on corruption, anti-corruption and the nature of fragility matter. International organisations 'exercise power by virtue of their ability to fix meanings ... Naming or labelling the social context establishes the parameters, the very boundaries, of acceptable action' (Barnett and Finnemore 1999, 711). The definitions therefore relate directly to the strategies and approaches of the agencies studied in Chapters 3 and 4.

Some social concepts are so embedded in our own conceptions, or so broad, that establishing one encompassing definition is not feasible. In 1905, Weber did not find it feasible to provide a definition of one of the central concepts to his writings - capitalism - on the grounds that it could only be seen as a 'complex of elements associated in historical reality which we unite into a conceptual whole from the standpoint of their cultural significance' (Weber 1930, 1). Good definitions are elusive, but should nevertheless be pursued. Corruption, anti-corruption and fragility are all broad concepts that should be unpacked to be truly meaningful for strategic responses.

The aim of this chapter is to understand the defining characteristics of a stabilising anti-corruption intervention. Traditional anti-corruption reforms, aimed at building good governance, are at best ineffective and at worst harmful in fragile contexts. Effective anti-corruption activities will target the types of corruption that matter most for fragility, but be careful not to do more harm than good. Finally, stabilising anti-corruption interventions need to happen earlier and require less capacity to implement than is the norm today. 


\subsection{UNDERSTANDING CORRUPTION IN A FRAGILE CONTEXT}

The investigation, prevention and prosecution of corruption are profoundly influenced by how corruption is defined (Philp 1997, 437). Our understanding of corruption also affects which anti-corruption activities we want to pursue. Aid agencies' existing anti-corruption strategies are based on an understanding of corruption that centres on individual acts of petty corruption. However, it is more useful to regard corruption as an act that distorts the political process, particularly when the aim is to reduce fragility.

Corruption is an act that corrodes institutional structures that promote a shared public interest. As Philp $(2012,31)$ argues, corruption in fragile states is intrinsically linked to the concept of public interest. In the absence of a formal legal framework, and shared norms for public office, corruption will often be interpreted as anything going against the public interest. Corruption should not be confused with ordinary criminal acts or misdemeanours. Philp proposes the following definition of corruption of specific relevance for fragile states, which incorporates elements of politics, public interest, and public office norms:

Corruption in politics occur where a public official (A), acting in ways that violate the rules and norms of office, and that involves personal, partisan or sectional gain, harms the interests of the public (B) (or some sub-section there-of) who is the designated beneficiary of that office, to benefit themselves and/or a third party (C) who rewards or otherwise incentivises A to gain access to goods or services they would not otherwise obtain. (Philp 2012, 34)

This definition comes closest to incorporating the characteristics of corruption that matter most for fragile states. Importantly, it shows that public office and public interest are separate but interlinked concepts, and can be combined in a definition of corruption. Unfortunately, it lacks the brevity and elegance to be a viable alternative for the current, inadequate definitions used by aid agencies.

\subsubsection{Public Office versus Public Interest Centred Definitions}

A fundamental distinction exists between public office and public interest centred definitions of corruption. This distinction is particularly relevant for fragile states, where holders of public office less frequently act in accordance with the public interest, and the concept of public interest is not easily defined. 
A public office centred definition views corruption as an act of a public official who misuses delegated authority and the obligations of public office as a result of considerations of personal gain, which need not be monetary. The principal-agent logic is central to this understanding of corruption. Nye's (1967b, 966) definition of corruption as a deviation of the normal duties of a public role is widely used. Historically, in patrimonial or absolutist states the modern concept of public office did not exist. It is a recent ideal that jobs in the public sector are to be distributed fairly and according to merits, and do not function as a means of rent extraction (Grindle 2012). Even in modern public administrations, Weber's ideal-type bureaucracy is far removed from reality where administration is often messy, politicised, and bureaucrats can be corrupted (Downs 1967). Thus, the use of public office definitions can be problematic, particularly in a fragile state context.

A public interest centred definition considers a public official to have committed a corrupt act when induced to take actions for monetary or other rewards, which does damage to the public and its interests. Although this is a good reference point for judging misuse of powers, problems typically arise when attempting to define specific acts of corruption, as the public interest typically is not a uniform statement, but consists of voices from various groups with diverging interests. For fragile states, societal fragmentation and sometimes open conflict often prevent the establishment of a social contract, let alone a unified expression of public interest. There is, however, a difference between the existence of public interest and the promotion of a shared public interest. Huntington $(1968,25)$ defined public interest as:

not something which exists a priori in natural law or the will of the people. Nor is it simply whatever results from the political process. Rather it is whatever strengthens governmental institutions. The public interest is the interest of public institutions. It is something created and brought into existence by the institutionalisation of government organisations.

Huntington was concerned with political order when writing this passage, but it illustrates well the many ways in which public interest can also be interpreted, in this case in a state-centric way. Tilly (1985) presents a different view, arguing that the idea of expressing a unified public interest via a social contract in conflict-affected and fragile states is more aspirational than realistic. He points out that situations of war and conflict are characterised by competition between various coercive and self-seeking entrepreneurs, all striving to rule over as much territory 
and as many people as possible to increase their revenue and rent extraction base, and thus their competitive advantage (Tilly 1985, 169).

\subsubsection{Problems with Current Understandings of Corruption in Fragile States}

A standard definition of corruption has been adopted by most aid agencies, focusing on the misuse of public office or public power for private benefit. There are minor differences between the aid agencies when it comes to the exact definition. The World Bank defines corruption as 'the abuse of public office for private gain' (World Bank 1997a, 8). The EU adopts the definition used by the United Nations' Global Programme Against Corruption: 'abuse of power for private gain' (European Commission 2003b, 6). UNDP defines corruption as 'the misuse of public power, office or authority for private benefit' (UNDP 1999, 7). The United Nations Convention Against Corruption (UNCAC) does not provide a single definition of corruption. Chapter III of the UNCAC does, however, define a series of corrupt behaviours, such as bribery and embezzlement (UNODC 2004). A common denominator for the definitions is that they are all public office centred, and expected to be universally applicable for all types of country contexts, including fragile states.

The standard definition has many weaknesses. First, 'misuse' very much depends on who defines the proper use of power. For bureaucratic corruption (see definition further below), misuse would characterise behaviour that deviates from formal duties of the office holder. It could also be taken to include informal rules such as norms and public ethos. In a pluralistic system of government, misuse could furthermore describe political electives' misappropriate handling of public resources or actions against their formal obligations. However, the term misuse becomes meaningless when dealing with political corruption where the government is aware and supportive of corrupt acts.

The second part of the standard definition relates to public office or public power. The World Bank's use of public office is more restrictive than the use of 'power' by the two other agencies. The EU has by far the most wide-ranging definition by not specifying that power needs to derive from public office. Public officials gain power and authority through appointment and delegated powers, and politicians through being elected to their positions. Public power can be exposed to corrupt temptations in a range of areas, such as the judiciary, public procurement, 
business regulations, permits, international financial transactions, taxes, subsidies, public utility and a variety of government services (Lambsdorff 2007, 16).

Transparency International (TI) rejects the use of 'public', replacing it with 'entrusted' in their definition of corruption: 'abuse of entrusted power for private gain' (Transparency International 2012). Besides trying to overcome the public office problem described above, the perceived advantage of using 'entrusted' is also that acts of corruption are not limited to exchanges where at least one person is a public official so that non-state actors can be included. This is similar to the EU definition. The disadvantage is that the definition of corruption becomes even broader.

'Private benefit' is the least contested part of the definition. Whether the definition reads private benefit or private gain is of minor importance. Both can encompass the act of receiving money or valuable assets, as well as more intangible resources or gestures that can be to a person's benefit, such as benefits for relatives or promises of future favours. However, acts of corruption need not always be for private gain, but done to benefit one's family or community, or to secure the domination of one's political party or ethnic group. This relates to a more general problem with the standard definition: its technocratic, apolitical character. If corruption is not only driven by individual greed, but to secure the advantage of one's community or privileged group, then it becomes a question of politics: who gets what, when and how. ${ }^{1}$

The current definitions of aid agencies have further problematic features. Most current definitions of corruption are universal in character; they don't differentiate between corruption in developed countries and in fragile states. This is not meant as a call for cultural relativism but as a reminder that local rules and mores matter. When dealing with corruption in fragile states, one has to ask the question what corruption means in a context where you may have to rely on your community to avoid starvation, rape or torture, and authority is not easily questioned. This relates to the difficulty of establishing an objective public interest position. For example, many Afghans regard the high salaries of foreign consultants, the substantial profits made by contractors and the large overheads charged by NGOs to be a form of corruption, even though it is not criminal or an abuse of public office (Le Billon 2008, 355; OECD 2009, 2).

\subsubsection{Categories and Patterns of Corruption}

The concept of corruption covers a variety of more clearly defined terms. Paraphrasing Klitgaard, we must subdivide and unpack the vast concept 
of corruption (Klitgaard 1998, 4). Table 1.1 briefly summarises the most important categories of corruption. These concepts will be used throughout this study, where possible, instead of the catch-all concept of corruption. The rationale for subdividing corruption into its constituent parts is that different types of anti-corruption interventions can be expected to affect the below categories of corruption differently. For example, audits may be useful to detect fraud and embezzlement, but less effective in revealing nepotism.

Perhaps due to the lack of a clear universally accepted definition, corruption is often described through establishing dichotomous concept pairs. These are ideal types. However, such ideal types are useful for the analysis to illustrate that some patterns of corruption may matter more for efforts to reduce fragility than others. Corruption is endemic in most fragile states, penetrating the political cadres. This does not merit an exclusive focus on political or grand corruption, as several studies show how corruption at the top of the hierarchy also increases corruption at the lower levels, and that political corruption is typically upheld by systematised bureaucratic corruption (Fjeldstad and Isaksen 2008, 6). However, understanding the dynamics between political/grand corruption and bureaucratic/petty corruption is important.

Different categories and patterns of corruption will require different strategic and programmatic approaches. This was recognised in early models for corruption control developed by aid agencies, but recent approaches do not account for this as shown later in the book. No comparative studies have focused explicitly on whether certain types of corruption are more predominant in fragile states than in other contexts. Academic arguments can appear simplistic, such as that of Harstad and Svensson (2011) who present a theoretical model for why bribery may be more prevalent in poor countries and lobbyism more pronounced in rich countries, without any empirical basis. One should always be careful with generalisations across societies. However, as many fragile states display characteristics of neopatrimonialism, and usually lack good institutional checks-and-balances and oversight mechanisms, political and grand corruption may be allowed to take place for longer and on a greater scale than in countries where public accountability mechanisms are better established. The most egregious examples involve state capture, a phenomenon typically used to describe situations in transition economies where non-state actors (frequently firms with links to organised crime) are powerful enough to influence and shape government policy and regulation to their own benefit, or kleptocracy, where the political elite uses its power to enrich itself (Hellman et al. 2000). ${ }^{2}$ 


\section{Table 1.1 Categories of corruption}

\begin{tabular}{ll}
\hline $\begin{array}{l}\text { Categories of } \\
\text { corruption }\end{array}$ & Description \\
\hline Bribery & $\begin{array}{l}\text { The act of dishonestly persuading someone to act in one's } \\
\text { favour by a payment or other inducement. Inducements can } \\
\text { take the form of gifts, loans, fees, rewards, or other advantages } \\
\text { (taxes, services, donations, etc.) }\end{array}$ \\
$\begin{array}{l}\text { Embezzlement/ } \\
\text { Misappropriation }\end{array}$ & $\begin{array}{l}\text { Stealing or misdirecting funds or assets placed in one's trust or } \\
\text { under one's control }\end{array}$ \\
Facilitation payment & $\begin{array}{l}\text { A small payment, also called a 'speed' or 'grease' payment, } \\
\text { made to secure or expedite the performance of a routine or } \\
\text { necessary action to which the payer has legal or other } \\
\text { entitlement }\end{array}$ \\
The act of intentionally and dishonestly deceiving someone in \\
order to gain an unfair or illegal advantage (financial, political \\
or other) \\
Patronage, \\
clientelism and \\
pepotism
\end{tabular}

Note: The definitions draw on the following dictionaries and guides: Pearsall (2002), McLean and McMillan (2003) and Transparency International (2009) 


\section{Table 1.2 Patterns of corruption: dichotomy pairs}

\begin{tabular}{|c|c|c|}
\hline Political & vs & Bureaucratic/administrative \\
\hline $\begin{array}{l}\text { Manipulation of policies, institutions } \\
\text { and rules of procedure in the } \\
\text { allocation of resources and financing } \\
\text { by political decision makers, who } \\
\text { abuse their position to sustain their } \\
\text { power, status and wealth }\end{array}$ & & $\begin{array}{l}\text { Corruption in the public } \\
\text { administration, in the implementation } \\
\text { end of politics where the public meets } \\
\text { officials. Usually juxtaposed to } \\
\text { political and grand corruption }\end{array}$ \\
\hline Grand & vs & Petty \\
\hline $\begin{array}{l}\text { Acts committed at a high level of } \\
\text { government that distort policies or the } \\
\text { central functioning of the state, } \\
\text { enabling elites to benefit at the } \\
\text { expense of the public good. } \\
\text { Transactions are usually large in } \\
\text { scale. Grand corruption is sometimes } \\
\text { used synonymously with political } \\
\text { corruption }\end{array}$ & & $\begin{array}{l}\text { Everyday corruption involving small } \\
\text { payments, similar to bureaucratic } \\
\text { corruption but not necessarily in the } \\
\text { public sector. Also called survival } \\
\text { corruption: corruption pursued by } \\
\text { agents who may be grossly underpaid } \\
\text { and who depend on relatively small } \\
\text { but illegal rents to survive }\end{array}$ \\
\hline Controlled & vs & Uncontrolled \\
\hline $\begin{array}{l}\text { The country's ruling elite have a } \\
\text { relatively strict control of the } \\
\text { processes and proceeds of corruption. } \\
\text { In cases of controlled corruption, } \\
\text { businesses will also be able to forecast } \\
\text { and estimate the level of corruption, } \\
\text { and include it as a measurable expense }\end{array}$ & & $\begin{array}{l}\text { Corruption tends to be more common } \\
\text { and unpredictable. The rulers are not } \\
\text { in command of who will gain how } \\
\text { much, or from what. A decentralised, } \\
\text { disordered and irregular pattern of } \\
\text { corruption, generally considered } \\
\text { more harmful for economies }\end{array}$ \\
\hline Systemic/endemic & vs & Sporadic \\
\hline $\begin{array}{l}\text { Corruption is an integrated element of } \\
\text { the economic, social and political } \\
\text { system. State institutions are routinely } \\
\text { captured by corrupt individuals and } \\
\text { groups. People have few alternatives } \\
\text { to dealing with corrupt officials }\end{array}$ & & $\begin{array}{l}\text { Irregular patterns of corruption that } \\
\text { do not threaten the mechanisms of } \\
\text { control or the economy of a country } \\
\text { as a whole. Considered less crippling } \\
\text { than systemic corruption }\end{array}$ \\
\hline
\end{tabular}

Note: The definitions draw on the following dictionaries and guides: Pearsall (2002), McLean and McMillan (2003) and Transparency International (2009)

The patterns of corruption in Table 1.2 are useful as overall descriptors but are not mutually exclusive. Johnston (2005) has developed four syndromes of corruption which, unlike the above categories, are more scenario-based, complex representations of corrupt situations and thus able to capture a trajectory of development. These four syndromes are Oligarchs and Clans, Official Moguls, Elite Cartels and Influence 
Markets (Johnston 2005, 3, Chapters 4-7). ${ }^{3}$ The Official Moguls and Oligarchs and Clans syndromes are the most pertinent for fragile states. Official Moguls represents a centralised form of corruption, where a small ruling elite has captured the state. Strong patronage bonds often promote stability. A different scenario unfolds under Oligarchs and Clans, where a divided elite competes for power, and corruption is decentralised and uncontrolled, which can lead to violence and insecurity. Zaum (2012a; 2013) has used Johnston's syndromes to argue that the social costs of corruption in fragile states are greater with oligarchic corruption systems than with mogul-type corruption.

\subsubsection{Patronage and Clientelism: How Conceptual Understandings Matter for Strategy}

This last sub-section focuses on patronage and clientelism to illustrate how a strategic approach to reducing the negative consequences of these practices requires a deep understanding of their causes and effects. This is true for any type of corruption, but the choice of patronage and clientelism is not random, as aid agencies often have problems tackling these types of corruption that are systemic and not always detectable via financial audits.

Patronage is not necessarily corruption. Patron-client relationships need not take on forms that are considered corrupt, but they can. This study is interested in cases where patronage involves act of corruption. Patronage is, at times, viewed narrowly as an unmeritorious appointment to public office, and at other times viewed broadly as a manifestation of the political system of rent-seeking in a country. Patron-client networks of rent-seeking and political positioning are labelled clientelism for the purposes of this study, to clearly distinguish between patronage as a recruitment strategy and other broader clientelist practices. This distinction is crucial, and not widely appreciated by aid agencies or academics. The difference in whether patronage is seen as a source of jobs or a way to buy political support (clientelism) matters for stability.

Aid agencies' view of recruitment patronage as damaging is rooted in the Weberian conceptualisation of the move from patrimonial to rationallegal orders. Even though most aid agencies state that context matters and that one cannot impose Western traditions of Weberian bureaucratic systems onto societies in other contexts, particularly fragile states, the building of state capacity is normally synonymous with the establishment of a system of rational-legal bureaucracy. This dilemma is not new, nor unique for anti-corruption work. It is similar to the modernisation debate of the 1960s and 1970s. Myrdal's (1970) distinction between hard and 
soft states is illustrative of this thinking which is rooted in Weber's original logic. The hard states operate according to Weber's rational bureaucratic system, have objective policies and regulations, and are able to enforce these. In soft states, corruption flourishes as politicians and civil servants collude (Myrdal 1970, 208).

Viewing patronage practices as unreservedly damaging may be counterproductive. Governments in fragile states generally can't rely on impersonal, formal institutions and the rule of law to uphold their authority. Instead, power is distributed through 'a system of relations linking rulers not with the "public" or even with the ruled (at least not directly), but with patrons, associates, clients, supporters, and rivals, who constitute the "system"” (Jackson and Rosberg 1982, 19). The loyalty of clients is a valuable currency for patrons. In this view, the state is an arena where political actors compete over state resources (Lemarchand and Legg 1972). Patronage sets the informal rules of the game for reform.

Literature on public administration has long recognised the dilemmas of meritocratic appointment systems in Western countries (Peters 2001, 86-9). Grindle (2012) provides a rare comparative analysis of public appointment systems in six now developed countries and contemporary trajectories of patronage in four Latin American countries, showing that private and party interest was only slowly and gradually replaced with civil service bureaucracy. ${ }^{4}$ Patronage structures are retained even in developed countries today, often at the top level of government, to allow flexibility, ensure political support and commitment for key reforms, and protect leaders, particularly in times of fragility (Grindle 2012, 261).

Grindle's study is not concerned with unsystematic, top-level patronage appointments, which characterise the majority of political systems, but focus on patronage systems, defined as situations where 'discretionary appointment for personal and/or political purposes is a principal route to a nonelected position in government for a large proportion of those enjoying such positions' (Grindle 2012, 18). Interestingly, she considers the sale of public office an alternative and constraining form of staffing practice, as this short-term revenue-generating practice has brought instability and inflexibility to patronage recruitment systems (Grindle 2012, 67).

Grindle $(2012$, 32) rejects the claim that patronage systems are synonymous with incompetence. Patronage is 'above all, a form of recruitment and advancement for public service, not a category of performance or competence ... its weakness is its vulnerability to the caprice of those who manage such systems, not that it necessarily leads to corruption or incompetence' (Grindle 2012, 23). This narrow definition of patronage as a recruitment practice and organisational management 
tool allows for the co-existence of recruitment patronage and merit-based systems, according to their functionality, and distinguishes between recruitment and sale of public office. This is a key difference to the aid agencies' zero-tolerance approach.

Most other studies of patronage focus on clientilist practices, not systems for appointment to public office. In his study of US politics in the 1960s, Scott (1969) considers machine building, an institutionalised patronage practice, to have politically stabilising effects and to promote institution building by organising and incentivising voters. Johnston (1986, 468) echoes the view that patronage organisations, in the form of political machines that organise supporters, can be stable, an integrative form of corruption in Johnston's vocabulary. He distinguishes this form of patronage from nepotism and cronyism - these are disintegrative forms of corruption that reward a small group of family members or elites but exclude all other people, which often leads to grievances (Johnston 1986, 471).

Khan (1998) also shows how patronage serves different purposes in different contexts and across time. Political corruption and patron-client exchanges are seen as a way for incumbent elites to reach compromises with actors who would otherwise threaten the political stability of the system, but differences in patronage systems lead to different consequences for corruption in the countries studied. ${ }^{5}$ Khan considers patronage practices an effective way to maintain political stability in contexts where governments do not enjoy widespread legitimacy or have a monopoly on violence. Unfortunately, his analysis does not distinguish between patronage as a recruitment practice and as a way to buy political support.

Building on Booth and Seligson's (2009) legitimacy theory (see Chapter 2), the OECD recognises that

patronage in the Western state model is viewed as corruption that undermines both process and performance legitimacy. However, in hybrid political orders, patronage can provide sources of both input and output legitimacy; and in fragile situations it can provide the main means of managing violence, creating political alliances and maintaining social stability. (OECD 2010, 9)

This view is arguably more nuanced than that of most aid agencies. However, it still downplays Grindle's (2012) insights. Patronage is only seen to have useful functions in so-called hybrid political orders. Grindle's argument - that the political and administrative systems of OECD countries also have patronage features that serve distinct purposes - is not recognised. 
Patronage networks of the political elite are often seen to play a key role in determining political instability, often leading to conflict (United Nations 1998). However, Arriola (2009) specifies conditions under which patronage, or more specifically clientelism, following the definition applied in this research, can strengthen the stability of a regime. He argues that political leaders can 'employ patronage to facilitate intra-elite accommodation and thereby stabilize their regimes' (Arriola 2009, 1358). In other words, leaders of fragile states need to keep potential rivals within the fold in order to keep themselves in power. Interviews with elites in fragile states complement this view by proposing that patronage may be most damaging for stability in two scenarios: (a) when benefits are not distributed universally but exclude important segments of society, and (b) when patronage networks use violent means to exclude opponents from the political process/economic gains (Dix et al. 2012, 37).

Aid agencies, such as the World Bank, have typically sought to limit the political space for patronage by promoting so-called market-based reforms to limit state involvement, and promoting merit-based recruitment, often via the establishment of civil service commissions. However, such reforms may have unintended, negative consequences for stability. First, one should acknowledge that there are both expenditure and non-expenditure forms of clientelism. Clients may be directly materially rewarded, by getting a job, subsidy, special payments and so on, or indirectly rewarded via non-expenditure means such as receiving preferential treatment by the police, in dispute resolution, or getting first in line for services. Second, although economists tend to think of patron-client relationships in individual terms, between a public manager and a subordinate, a more important form of clientelism for fragile states is that between the government/political parties and groups in society. For example, a seemingly neutral market reform such as reforming and privatising the power sector would, from the outset, be seen as a way to reduce rent-seeking and limit the discretionary powers of public servants. However, in effect, such a reform can create more opportunities for corruption, particularly in the short run, by displacing corruption risks from the state agency into the political decision-making process. Political opponents and their clients may be disfavoured by, for example, rolling out the metering scheme in their geographical areas first. Such behaviour has been labelled market clientelism (Jenkins 2007, 163-9).

In summary, patronage and clientelism are interesting and policyrelevant corruption categories for work in fragile states, as their manifestations can have both stabilising and destabilising effects. They are often viewed in binary terms, as either stabilising or destabilising. Aid agencies, and many academics, view patronage as entirely destabilising, but 
some academics point to the stabilising effects of patronage systems, in particular patronage as a recruitment strategy (as opposed to the sale of offices which is considered destabilising). This scholarly work provides important grey tones to a picture otherwise presented in purely black and white. Aid agencies' zero-tolerance approach may unintentionally deprive governments in fragile states of an organisational management tool and complicate elite compromise.

\subsection{ANTI-CORRUPTION: EFFORTS TO REDUCE CORRUPTION HAVE MANY NAMES}

Anti-corruption activities seek to prevent or control corruption. They are a sub-set of measures to strengthen public accountability and governance. Anti-corruption can be defined narrowly with a focus on law enforcement and controller activities, or more broadly to include government and civil society actions to curb corrupt behaviour. Some organisations choose to label their activities as anti-corruption efforts and others opt for words like integrity, transparency and accountability. This is often more a matter of branding than difference in substance.

This section begins by presenting an overview of the different activities that can fall under the anti-corruption umbrella, then explains what relation the concepts of transparency, accountability and integrity have to anti-corruption, and finally discusses how anti-corruption relates to the concept of good governance. None of the interventions mentioned below were designed specifically for fragile states, but all have arguably been applied in these contexts. In other words, there are currently no clear guidelines for aid practitioners on what types of interventions work best in fragile states.

\subsubsection{The Universe of Anti-corruption Activities}

What qualifies as an anti-corruption intervention is debatable as aid agencies have diverging views and classifications. A basic classification into direct and indirect anti-corruption projects is often used to distinguish between different anti-corruption activities. Direct anti-corruption projects involve explicit support for, for example, anti-corruption agencies and commissions, while indirect anti-corruption projects only have the reduction of corruption as a stated implicit or secondary goal (Jennett 2006). Indirect approaches often use a so-called mainstreaming strategy. Mainstreaming is a strategy to implement indirect anti-corruption interventions in all sectors and at all intervention levels of development 
cooperation (Chêne 2010, 2). Indirect interventions have the benefit of concealing the sensitive, political-term corruption within the broader umbrella of good governance:

In some countries it is downright impossible for donors to suggest a clear-cut anti-corruption project. The challenge is then to rewrite the project documentation so that it becomes less of a threat to the partner government ... This complicates the classification of projects. (Jennett 2006, 3)

Different aid agencies favour different types of anti-corruption interventions. For example, the World Bank supports direct anti-corruption projects less than the EU and UNDP. The distinction between direct and indirect anti-corruption projects is a useful analytical point of departure, but does not take into account the various strategic and programming choices which aid agencies face. Agencies can take three general approaches when supporting governments in curbing corruption: technical assistance, civil society support, and/or general budget support. They can also improve their own financial management and quality assurance systems and/or work on international norms and standards via multilateral institutions or programmes. ${ }^{6}$

This study focuses on strategies and programmes for technical assistance and civil society support. However, it is recognised that agencies' own risk management systems will influence their programming, as will international initiatives and partnerships. Nevertheless, anti-corruption strategies and programmes to increase the accountability of government counterparts are distinct, separate activities. The universe of anticorruption interventions is wide and varied. For each possible programme, a range of choices would ideally be made regarding:

- the overall strategic approach, where a classic distinction is made between prevention, enforcement and education, but recent concepts such as transparency, accountability and integrity are also sometimes confused with strategies;

- what kind of corruption one is aiming to reduce and whether reform is happening at the central or decentralised level of government; and

- how local contexts and politics matter for the selection and design of the intervention.

Later chapters will show that the choices made for the first two bullets often reflect the decision makers' theoretical orientation and what is feasible within the specific organisational setting. The last bullet on local 
contexts and politics is often not explicitly addressed in the strategies and programming documents of aid agencies.

\subsubsection{Transparency, Accountability and Integrity}

What are the differences and similarities between efforts to reduce corruption, improve transparency, strengthen public accountability and bolster integrity? There are important conceptual differences, but no clear demarcations between the definitions. Transparency is the most clear and uncontested concept. Transparency International, an NGO, defines it as a characteristic of actors of 'being open in the clear disclosure of information, rules, plans, processes and actions' (Transparency International $2009,44)$. The transparency movement was based on the key assumption that an increase in transparency would reduce opportunities for corrupt behaviour. A decade later, scholars are realising that this assumption needs to be modified (Kolstad and Wiig 2009; Lindstedt and Naurin 2010). For example, publishing a government budget is only a first step. Actors within government or civil society must follow up on this information and hold wrongdoers accountable (Peters 2007, 15-16). Even the basic assumption that transparency produces accountability can be questioned, as little evidence exists as to how information accessibility improves the quality of governance (McGee and Gaventa 2010, 4).

Efforts that strengthen public accountability also often reduce the space for corruption. The idea of accountability is historically rooted in the bookkeeping and auditing profession. Accountability is about providing answers for actions and about suffering sanctions in case of misconduct. Public accountability is about linking those in public office who owe an account to those whom it is owed. Some conceptual confusion can be reduced by distinguishing between accountability as a virtue and as a mechanism. As a virtue, accountability is a desirable state of states, governments, firms or officials. Accountability can also be studied more descriptively as a mechanism, and here accountability is the independent variable that influences the behaviours of different actors (Bovens et al. 2014, 2-9). However, the concept has so far proved difficult to operationalise, even translate, in developing country contexts. Within the broader governance literature, accountability ideally involves both answerability (the responsibility of government to provide information about and justification for its actions) and enforceability (the possibility of sanctioning wrongdoers) (Goetz and Jenkins 2001). However, most aid interventions aim at improving answerability and rarely involve strong enforceability (McGee and Gaventa 2010, 4-5). Aid agencies often focus on social accountability and on the promotion of 
citizen voice to contribute to improved public sector performance, and have had mixed experiences. Again, just providing information or transparency is often not enough. Improved accountability lies in the relationship between the state and society, so both parties need to be included in strategic and tactical responses (Fox 2015).

Many civil society organisations and aid agencies have moved on to integrity as a new favoured term, particularly when working in fragile states. Integrity is defined as actions "consistent with a set of moral or ethical principles and standards, embraced by individuals as well as institutions, that create a barrier to corruption' (Transparency International 2009, 24). Where accountability is inherently defined by the relationship between citizens and the state, integrity does not have this duality, as it focuses on the individual or organisation in question. Most often the use of integrity refers to institutional integrity, not the traditional meaning of an individual's personal ethics, honesty and moral stature. The use of integrity provides flexibility and is less confrontational than insisting on accountability between governments and citizens, but this may also be a weakness as it is not clear how the build-up of integrity within an institution can lead to sustainable change without taking into account the broader governance context. One can also talk about the integrity of the public sector as a whole or the national integrity system (a concept first championed by Transparency International). The meaning is the same. A system with high integrity has low levels of corruption and high levels of accountability and ethics.

\subsubsection{Good Governance and Good Enough Governance}

The concept of good governance is closely related to anti-corruption, as many of its defining characteristics, such as the rule of law, political accountability and a transparent and accountable public administration, are also essential elements when addressing corruption. Good governance as a concept thus encompasses anti-corruption. However, not all anticorruption strategies are rooted in good governance concepts. Monitoring is an effective anti-corruption strategy that has no direct association with good governance characteristics. The term bad governance was reportedly first used by the World Bank in the 1980s to characterise countries marked by "personalisation of power, lack of human rights, endemic corruption and un-elected and unaccountable governments' (Bøås 1998, 119). Good governance, in turn, was the opposite (Weiss 2000, 801).

When the representatives of aid agencies speak of good governance, they are rarely themselves univocal (Doornbos 2001). Good governance bears many meanings in the development community, and important 
differences exist both internally between donors and between donors and recipient governments (Smith 2007, 3-6). Grindle (2007) presents a forceful critique of the concept of good governance, questioning the usefulness of aid agencies' usual long list of desired institutional changes and traditional capacity-building initiatives. By introducing the concept of good enough governance, Grindle $(2007,554)$ aims to show that

not all governance deficits need to (or can) be tackled at once, and that institution- and capacity-building are products of time; governance achievements can also be reversed. Good enough governance means that interventions thought to contribute to the ends of economic and political development need to be questioned, prioritised, and made relevant to the conditions of individual countries. They need to be assessed in the light of historical evidence, sequence, and timing, and they should be selected carefully in terms of their contributions to particular ends such as poverty reduction and democracy.

This study shares Grindle's view about the need to explicitly manage trade-offs, priorities and sequencing, particularly in fragile contexts. Of course, the focus of this study is narrower, both in terms of governance interventions (anti-corruption) and the 'ends' (stability) referred to in the quote above. Building stable, resilient institutional structures is not about promoting good governance, but about supporting good enough governance.

The World Bank, the EU and UNDP agree that good governance relates to the manner in which a country's resources are managed, but they also have important areas of disagreement between them. The differences arise when definitions expand beyond the minimum. The World Bank laid out its vision on governance, and good governance, in its 1994 report titled 'Governance: The World Bank's Experience'. Good governance is

epitomized by predictable, open, and enlightened policy making (that is, transparent process); a bureaucracy imbued with a professional ethos; an executive arm of government accountable for its actions; and a strong civil society participating in public affairs; and all behaving under the rule of law. (World Bank 1994, vii)

The report goes on to emphasise the Bank's non-political role and the primacy of public sector management in its good governance work (World Bank 1994, vii-viii). Much has changed over time within the World Bank in terms of its approach to governance, but much also remains of the early conceptualisation which almost equates governance with government. For example, the World Development Report 1997, 
'The state in a changing world', rarely mentions 'governance' and not once 'good governance'. Good government is the central concern and is defined primarily in terms of state capability and effectiveness (World Bank 1997c, 3). Today, the World Bank still assesses good performance in terms of capability and effectiveness. The Country Policy and Institutional Assessment (CPIA) rates low-income countries on 16 criteria, grouped into four clusters. The clusters are: (a) economic management, (b) structural policies, (c) policies for social inclusion/equity, and (d) public sector management and institutions. The fourth cluster is most relevant for anti-corruption and has five criteria: property rights and rule-based governance; the quality of budgetary and financial management; the efficiency of revenue mobilisation; the quality of public administration; and transparency, accountability and corruption in the public sector. The CPIA matters as the score heavily influences the allocation of funds from the International Development Association (World Bank 2011b). Thus, these internal operational criteria in some ways provide a better reflection of the organisation's view of good governance than do formal definitions in policy documents. Overall, good governance is akin to effective administration and good economic performance.

UNDP laid the foundation for its conceptualisation of good governance in 1997 with the publication 'Governance for sustainable human development'. As the title suggests, the report emphasises the indivisible links between governance and human development, arguing that human development cannot be sustained without good governance and that governance cannot be sound without human development. Participation, transparency, accountability, the rule of law, and effective and equitable use of resources are core principles of good governance. Moreover, good governance means that 'political, social and economic priorities are based on broad consensus in society and that the voices of the poorest and the most vulnerable are heard in decision-making over the allocation of development resources' (UNDP 1997, 4). Democratic governance and equity are thus stressed as values inherent to good governance. Throughout the document, it becomes clear how traditional UN values such as human rights and human development conceptually invade the good governance definition until their conceptual spaces become difficult to separate.

The EU operates with different views on good governance, depending on the institutional outlook. A major distinction is between good governance internally within EU institutions and good governance as practised by aid recipient countries relevant for the EU's development work 
(Spence 2011, 61-70). This study does not discuss the internal dimensions of EU governance." The 'Communication on Governance and Development' from 2003 is the first policy document to firmly establish the importance of governance in the European Commission's development programming. It defines governance simply as the state's ability to serve its citizens. Good governance is seen as an evolution towards more sophistication and the values that are inherent to the EU:

As the concepts of human rights, democratisation and democracy, the rule of law, civil society, decentralised power sharing, and sound public administration gain importance and relevance as a society develops into a more sophisticated political system, governance evolves into good governance. (European Commission 2003a, 4)

This view was reinforced in the 'European Consensus on Development' from 2005, providing not only a common EU framework for understanding good governance, but also a deliberate alternative to the World Bank view rooted in the Washington Consensus (Carbone 2010, 15-18). The emphasis is on human rights, democratic principles and the rule of law (European Council 2006b, 13).

A communication from the Commission in 2006 further underlines that a compartmentalised approach to governance must be avoided. Between the lines, the communication argues that state-centric definitions of good governance with a focus on the effectiveness of government do not adequately account for the multiple dimensions of good governance. An efficient state is not enough to promote sustainable development. Throughout the document, the Commission equates good governance with democratic governance (European Commission 2006b, 6).

\subsection{FRAGILITY, STABILITY, RESILIENCE AND STATE BUILDING}

This section shows how the concepts of state fragility, stability, resilience and state building relate to each other, illustrates their differences and explains what that means for development aid. It also compares the understandings and formal definitions of the three agencies. This review is used to construct a model that illustrates that stabilising interventions need to happen earlier and require less capability to implement than traditional activities aimed at promoting good governance.

Fragility is a relatively new concept in both academia and aid policy. The international community showed some resolve to 'save failed states' in the 1990s after the Cold War had ended, but it was the terrorist attacks 
of 11 September 2001 that put failed states at the top of the international agenda. Fragility is a spectrum that can encompass the failed state label and others. It is more useful to avoid binary notions (failed or not) and move to a continuum of fragility that is multi-dimensional (DIE and UNDP 2009, 6).

\subsubsection{What is a Fragile State and How Can Fragility be Reduced?}

The definition provided by the OECD's Principles for Good International Engagement in Fragile States and Situations represents the aid community's shared view of fragility: 'States are fragile when state structures lack political will and/or capacity to provide the basic functions needed for poverty reduction, development and to safeguard the security and human rights of the populations' (OECD 2007, 2).

There are of course differences between the individual aid agencies. However, the OECD definition captures some important commonalities: a focus on the state, poverty reduction, and security. This fails to account for the importance of different types of vulnerabilities, the importance of resilience rather than development and the notion that fragility needs to be understood both in the context of the state and its institutions and of the broader society.

The World Development Report (WDR) 2011 defines fragility and fragile situations as "periods when states or institutions lack the capacity, accountability, or legitimacy to mediate relations between citizen groups and between citizens and the state, making them vulnerable to violence' (World Bank 2011a, xi). Central concepts to the understanding of fragility in the WDR 2011 are organised violence; security, economic or justice stresses; the confidence or trust between groups of citizens divided by violence; elite pacts; institutions (understood as the informal and formal rules of the game); and state legitimacy and accountability (World Bank 2011a, xv-xvii). The transformation of institutions, based on a restoration of confidence, is necessary to reduce stresses that lead to fragility, according to the WDR 2011.

Putzel and Di John $(2012,7)$ make the astute observation that the 'counterpoint to state fragility is not development, but state resilience, which may be a stepping stone to more dynamic development, or a plateau marked by economic stagnation, beyond which it is difficult to pass'. This is an implicit criticism of definitions of fragility that are based on a country's performance in terms of traditional development outcomes. This study adopts Putzel and Di John's definition of fragility, as it isolates the problems facing developing countries in general and focuses 
on the special characteristics of fragile states. Important drivers of fragility are ones that provoke violence and lead to state collapse, such as

the lack of a basic legitimate monopoly over the means of large-scale violence, the absence of control over taxation, the failure of state organisations to operate in significant territories of the country and the existence of rival rule systems that take precedence over the state's rules. (Putzel and Di John 2012, v)

This study has deliberately not focused on so-called post-conflict societies but opted to address broader issues of fragility. There are special challenges for post-conflict countries when it comes to corruption control, which are only discussed briefly below, such as peacekeeping forces and peace treaties. ${ }^{8} \mathrm{~A}$ fragile state does not have to be affected by violence or war, but many fragile states do have a legacy of conflict. Violent conflict can be seen as 'a cause, a symptom or a consequence of fragility' (DIE and UNDP 2009, 7). Aid agencies have already identified a number of factors specific for post-conflict contexts that are expected to matter for anti-corruption strategies and programming, such as how the war ends, how the peace agreement is crafted, whether there is a clear winner emerging from the conflict, whether there is a legacy of wartime corruption, the level of chaos in the immediate aftermath of conflict, potential resource wealth and the level of destruction of state structures (UNDP 2010b, 7-19).

To add to this understanding, the study now briefly explores insights on the nature and characteristics of modern conflicts, and their aftermaths. Three areas highlighted in the literature are explored: (a) the characteristics of the political settlement/peace agreement, (b) the different dynamics of conflict between societal groups, and (c) the tension between security and development objectives.

There are inherent problems in relying on peacemaking and state building by international actors in fragile contexts to solve problems, including problems of corruption. In the thought-provoking essay 'War Making and State Making as Organised Crime', Tilly (1985) provides a historical account of Europe in the sixteenth and seventeenth centuries, and discusses what the lessons from the state-building process of Europe are for developing countries today. In these two transformative centuries, Europe went from a Medieval, feudal system of governance with overlapping authorities toward the Westphalian system of nation-states based on the principles of sovereign territories' political selfdetermination, mutual recognition and non-interference in the domestic affairs of other states. In this process of state making, Tilly argues, war 
making was an essential driver and made it necessary for the party seeking ultimate authority within a territory to extract resources from the local population. To ensure this funding base, coercive and self-seeking entrepreneurs would operate protection rackets similar to organised crime gangs. Tilly's (1985, 169-70) argument goes as far as to stress

the interdependence of war making and state making, and the analogy between those processes and what, then less successful and smaller in scale, we call organised crime. War makes states, I shall claim. Banditry, piracy, gangland rivalry, policing and war making all belong on the same continuum.

The links between corruption and organised crime are often overlooked by corruption scholars. The nexus between state making and organised violence, with its associated processes of corruption, has not received much attention since Tilly's (1985) thesis.

Suhrke and Berdal (2012) provide a contemporary analysis, arguing that the usual prescription of institution building in the public sector and the security sector, supported by an international force to stabilise the peace, is reductionist as it fails to take into account important sociocultural and political economy factors. Moreover, the whole concept of post-conflict is an oxymoron, as collective violence rarely stops with a peace agreement. Institution building is not a panacea for overcoming fragility, as this very process can feed warlord politics and strife. The institutionalist approach to peace building is also often referred to as the liberal peace. In a liberal peace, a social contract has not been forged between individuals and groups in a given society. Instead, the international community pushes for an end to war and immediately seeks to build up a state with liberal market economy and democratic rule (Berdal 2012, 314; Suhrke 2012a, 3-6). Four different ideal types of post-war environments are presented to counter the 'tendency in the policy discussion as well as the academic literature to assume that there is one, predominant type of post-war situation, which has certain generic features' (Suhrke 2012a, 7). These are described in Table 1.3.

The expansion of peacekeeping activities means that Victor's Peace and Loser's Peace rarely happen nowadays. Most civil wars now end in an internationally negotiated compromise. More scholarly work is needed to understand the impact of different fragile state contexts on corruption dynamics, and vice versa. The ideal types in Table 1.3 are a starting point for post-war environments. It is noteworthy that Afghanistan is characterised as Divided Peace in the period 2001-05, but is considered to have fallen back into outright conflict in the subsequent period (Suhrke 2012a, 12-17). 
Table 1.3 Suhrke: different post-war environments

\begin{tabular}{ll}
\hline \multicolumn{1}{c}{ Victor's peace } & \multicolumn{1}{c}{ Loser's peace } \\
\hline $\begin{array}{l}\text { Total non-compromising conflict, total } \\
\text { victory/defeat, unified state power with } \\
\text { monopoly on violence when conflict } \\
\text { ends, unconstrained sovereignty }\end{array}$ & $\begin{array}{l}\text { No clear winners, losers or compromise, } \\
\text { the party that lost the war retains the power } \\
\text { to sabotage the new order, violence } \\
\text { targeted against particular social segments } \\
\text { Example: Ex-confederate states of the } \\
\text { United States (1865-77), Guatemala 1996 }\end{array}$ \\
\hline \multicolumn{1}{c}{ Divided peace } & \multicolumn{1}{c}{ Pacified peace } \\
\hline $\begin{array}{l}\text { Pacification of conflict by international } \\
\text { actors, no grand bargain between key } \\
\text { factions, conflict between interveners and } \\
\text { nationals, societal divisions remain } \\
\text { unsolved }\end{array}$ & $\begin{array}{l}\text { Pacification of conflict by international } \\
\text { actors, inclusive peace negotiations and } \\
\text { grand political bargain, no conflict } \\
\text { between interveners and nationals } \\
\text { Example: Afghanistan 2001-5 }\end{array}$ \\
\hline
\end{tabular}

Source: Suhrke (2012a, 7-18)

Using Johnston's (2005) corruption syndromes, Zaum (2012a) has argued that stable political settlements are associated with mogul-type corruption. In other words, political settlements which have a clear winner (Victor's Peace) and allow for strong, centralised rule will be more stable and corruption will have less of a destabilising effect. Settlements that leave factions relatively autonomous (politically and economically) in a decentralised system of governance (Pacified Peace) will invite oligarchic corruption - the most damaging type of corruption in fragile states. This resonates with the hypothesis that patronage systems that manage to be inclusive and universal in character will be less destabilising than ones that are exclusive, particularistic and fragmented (Booth and Therkildsen 2012, 11-12). This both relates to how patronage systems are affected by the heterogeneity of the population (whether patronage systems work across ethnic lines) and to the behaviour of elites (whether non-elites have access to the benefits of the patronage system).

The importance of the nature of political settlements for corruption patterns indicates that peace negotiations may play a key role in anti-corruption efforts. However, aid agencies have not been successful at integrating corruption concerns in peace negotiations (Spector 2010). Long-term development objectives are rarely aligned with the immediate political and military priorities of peace negotiators.

In 2007, donor countries signed an international accord committing themselves to focus on state building as the central objective of their 
effort in fragile states (OECD 2007). State building is defined as endogenous action to enhance the capacity, institutions and legitimacy of the state with a view to enhancing their effectiveness, in the context of political negotiations between the state and societal groups (OECD 2008b, 1).

Ashraf Ghani and Claire Lockhart describe the centrality of the state-building project for today's policy makers with an analogy from the economics literature:

Just as the firm is the most effective unit of organization in the economy, the state is the most effective form of organization of the polity. Only the state can organize power so as to harness flows of information, people, money, force, and decisions necessary to regulate human behaviour. (Ghani and Lockhart 2008, 4)

They show how the perception of the primacy of the state implicit in the state-building agenda is mainly based on the early European state formation process from the sixteenth century and onwards, where order was established via a monopoly of violence, and argue that its prescriptions no longer apply in a globalised world (Ghani and Lockhart 2008, 223). Their solutions, however, fall back on changing the rules of the game in what they call failed states to overcome poor governance and rampant corruption via multilateral organisations and global capital.

This institutionalist approach, called post-liberal governance by its critics, often views the problem of fragile states in economic terms: the institutional structures of fragile states prevent them from benefiting from global capital (Ghani and Lockhart 2008, 24; Chandler 2010, 6-7). Implicit in the concept of state building, say the critics, is the goal of promoting good governance, often by transplanting Western blueprints of good practice to contexts where they do not fit (Chandler 2010, 1). Jackson (2011) illustrates why the state-building, peacekeeping, postconflict reconstruction and development agendas continuously challenge decision makers to strike a delicate balance between security and development objectives. Although policy papers all highlight the need for balancing short-term security objectives with longer-term development priorities, practice suggests that security usually trumps development priorities. The UK's experience in Sierra Leone and Afghanistan are taken as cases of security-led development, which is vulnerable to elite capture and may prioritise the security of the international system (i.e. fight against terrorism) over actual legitimate state building (Jackson 2011, 1814, 1819). This resonates with Doig and Tisné's (2009) argument that the anti-corruption agenda is often not prioritised in the 
post-conflict phase. Below, this study introduces a model for how aid agencies should engage to curb corruption in fragile states. It distinguishes between interventions aimed at building good governance, in a traditional state-building fashion, and interventions seeking to reduce fragility.

In short, the broader literature on peace and conflict reveals some pertinent dimensions of fragility. First, fragile states are different, and different environments may entail different corruption dynamics. Second, an institutionalist approach to state building may in itself lead to strife. Third, when security objectives trump state-building objectives, the development agenda, and thus the anti-corruption agenda, may be even further relegated. Finally, negotiations around the political settlement of conflict can leave lasting trajectories for corruption, but aid agencies are normally not successful in promoting the anti-corruption agenda at this stage. These useful dimensions of state fragility have not yet been embraced by the three aid agencies analysed in this study, at least not at the operational level. The WDRs are produced by the World Bank, but it takes significant efforts for a large bureaucracy to ensure that analytical insights become operational practice.

The World Bank used the term 'Low-Income Countries Under Stress (LICUS)' until January 2006, when the Bank adopted the term 'fragile states', changing its focus from economic indicators to one of state effectiveness. A fragile state is characterised by weak policies, institutions and governance (World Bank 2006a, vii, xxiii). This definition has recently been changed to 'fragile situations' to avoid any negative connotations regarding state-centric approaches. The World Bank's list of fragile situations is based on (a) a harmonised average Country Policy and Institutional Assessment (CPIA) country rating of 3.2 or less, or (b) the presence of a UN and/or regional peacekeeping or peace-building mission during the past three years. ${ }^{9}$ Thus, the nuanced understanding of fragility provided in the WDR 2011 is operationalised rather crudely and mainly based on existing development indicators in the standard CPIA. Parts of the organisation acknowledge that this definition 'sounds bland, almost benign' and display more sophisticated understandings of the drivers of fragility (World Bank 2012c, 2). However, official definitions and categorisations matter most. The German Development Institute (DIE) and UNDP consider the CPIA mainly to be an internal tool for the Bank and a measure of how well a country complies with Bank policies, and warn that '[e]xtreme caution' should be exercised when using the CPIA for analytical purposes. Nevertheless, other aid agencies use the CPIA for their international decision-making processes. For example, 
the European Commission used the CPIA to benchmark EU aid to fragile states (DIE and UNDP 2009, 8, 50-52).

UNDP defines fragility in broader terms than the World Bank, and has more emphasis on dimensions of crisis, conflict and vulnerability on the one hand, and political issues such as government legitimacy on the other. Fragility is seen as a continuum, not a fixed state. The Governance for Peace report offers a loose definition of fragile contexts as: "those countries and territories experiencing armed conflict, emerging from armed conflict, or affected by acute political, social, and economic vulnerability, and susceptible to chronic forms of organized criminal violence' (UNDP 2012a, 17).

UNDP's definition has little emphasis on state functions and service delivery. Instead, a key distinction between fragile and non-fragile states is that, for the former, external pressures can destroy the social contract in society and thereby undermine the legitimate functioning of the government (UNDP 2012a, 16-19). Being part of the UN family, and considering the UN's role of peacekeeping activities, it is not surprising that UNDP would have an understanding of fragility which is more concerned with crisis and conflict.

The EU defines fragility similarly to the World Bank in terms of state functions and effectiveness, in particular relating to service delivery, but adds elements of human rights, rule of law and democracy. However, similarly to UNDP and to some extent the WDR 2011, the language also centres on the notion of a social contract:

Fragility refers to weak or failing structures and to situations where the social contract is broken due to the State's incapacity or unwillingness to deal with its basic functions, meet its obligations and responsibilities regarding service delivery, management of resources, rule of law, equitable access to power, security and safety of the populace and protection and promotion of citizens' rights and freedoms. (European Commission 2007f, 5)

Fragility understood by the EU, and the World Bank, is not very different from how these two institutions view bad governance. The solution to fragility could therefore easily be assumed to be the promoting of good governance, via institution building. Such a strategy would fail to recognise the special dynamics of fragile states, with the stresses that make conventional institution building a Sisyphean task.

Stability is not the opposite of fragility, but ingrained in efforts to promote resilient institutions that can better absorb shocks is evidently also a desire to introduce measures that can provide some stability. However, stability as a goal in itself is controversial. The practice of Western governments in supporting authoritarian regimes to maintain 
stability and allegiance, particularly during the Cold War, via so-called authoritarian bargains nuances the debate on the value of stability (Muggah et al. 2012, 1). The so-called Great Game between various powers over the strategic location of Afghanistan, starting before the Cold War, is a case in point (Saikal 2012, 6). Such stability has been characterised as short-lived and unsustainable, as states can try to 'maintain stability through coercion and patronage networks, but those with high levels of corruption and human rights abuses increase their risks of violence breaking out in the future' (World Bank 2011a, 8). Stability can be fragile if short-term gains are obtained by undermining or bypassing processes that are important for longer-term political and societal stability. Peace agreements negotiated by the international community have often only achieved fragile stability because they have focused on quick wins by temporarily ignoring important, powerful opposition parties. Stability is sustainable if the security and wellbeing of a community can be secured through the mutually agreed rules of the game and do not depend on future acts of violence to correct real or perceived injustice.

When practitioners refer to stability they often mean political stability. However, societal stability is also important, including for political stability, and particularly in fragile states where government is often very weak or non-existent. There are many conceptualisations of political stability, and different methods and indices used to measure political instability create further confusion. Such indices show a troubling lack of convergence and consistency (Stepputat and Engberg-Pedersen 2008, 25). Approaches to the study of political stability have traditionally focused on: (a) the absence of violence, (b) government longevity/duration, (c) the existence of a legitimate constitutional regime (rule of law), (d) the absence of structural change, and, in some cases, (e) societal attributes (Hurwitz 1973). Most definitions tend to focus on the durability of governments and state institutions. In general, the difference between governmental stability and the stability of a political system is not appreciated. More importantly, numerical indices fail to recognise the interlinkages between the above variables that matter for stability. The problems with existing measurements have led scholars like Dowding and Kimber $(1983,229)$ to define 'a stable political object as one that possesses the capacity to prevent its own forced non-survival' and to argue that stability cannot be quantified and that one therefore cannot talk about degrees of stability.

Huntington (1968, 4-12) believed that political instability and disorder arise when rapid social change and political mobilisation of societal groups leave political organisation unable to adapt fast enough, thus 
stressing the interplay between dynamics in society and the political system. If one views stability as just political stability, the outlook becomes state-centric. This matters for anti-corruption strategies as it may determine which types of corruption are considered most destabilising. State-centric approaches tend to focus on bureaucratic corruption.

More recently, so-called fragility indices have mushroomed. These can include dimensions of security, economy, and social and environmental issues in addition to the political dimension. The difference in emphasis on the various dimensions of fragility found between the different indices is problematic. Fragility indices are often produced by aid agencies such as the World Bank and the UN or by Western universities or think tanks. The DIE and UNDP (2009, 34-5) provide a candid assessment of these fragility indices, stating that most of them 'barely satisfy scientific standards' and that even though they are used by aid agencies to monitor progress and decide on aid allocations, they are 'highly aggregate and abstract representations of complex social systems, which makes them hard to interpret and error prone'. ${ }^{10}$

In summary, the defining challenges of fragile states relate to crisis, conflict and other forms of vulnerability. However, the formal definitions of the World Bank and the EU focus on a country's economic performance. The goal is not to promote economic growth but to develop, restore or strengthen policies and institutions that promote the legitimacy of shared governance structures, safeguard human security and wellbeing, and reduce the risk of conflict. To escape fragility, countries need resilient institutions that can weather the storms, but state-building interventions often focus on promoting good governance and building up state institutions without considering the effects in terms of societal stability.

\subsubsection{From Paris to Busan: Aid Agencies' Principles for Engagement in Fragile States}

In order to understand the anti-corruption strategies and practices of the major multilateral aid agencies, one must also be familiar with the aid effectiveness agenda manifested in the Paris Declaration on Aid Effectiveness from 2005 and its associated Accra Agenda for Action from 2008. The New Deal Agreement between fragile states and aid agencies at the Busan High Level Forum on Aid Effectiveness in November 2011 restated many of the same principles, but focused on the responsibility of aid agencies to work differently in fragile states (OECD 2005, 2008a, 2011). 
The Paris Declaration and Accra Agenda represent an agreement between developed and developing countries where the guiding principles are ownership, harmonisation, alignment, managing for results and mutual accountability. These principles were promoted to overcome the problems of traditional aid delivery modalities, such as conditionality. The principles of harmonisation, ownership and mutual accountability pose special challenges for anti-corruption activities.

Harmonisation means that duplication of activities should be avoided by way of specialisation. The ambition is to move towards a division of labour between the aid agencies both thematically and in terms of workload in individual countries. The basic principle of comparative advantage is therefore central to today's aid policies. However, although the principle of comparative advantage may lead to greater effectiveness, it proves difficult to apply in practice for aid agencies. As shown below, bureaucratic competition and incentives for organisational survival run counter to the harmonisation principle. Few studies exist of aid coordination and harmonisation in the area of anti-corruption. Marquette (2001) argues that although aid agencies claim to coordinate and to have areas of comparative advantage, this is typically not the case. Her review, which included the World Bank, the EU and UNDP, found that the reality was 'business as usual' (Marquette 2001, 32). Chapter 4 in this study shows that aid coordination is still a problem, at least in Afghanistan.

The ownership principle means that developing countries themselves are primarily responsible for setting their own development objectives. This can create problems for anti-corruption work in particular, if corrupt governments are expected to champion reforms against their own interest. Some experts therefore argue that national ownership of anti-corruption projects is 'neither feasible, nor necessarily advisable in many cases' (Devine et al. 2010, 5). In fragile states, the conflict between the principle of national ownership and the objectives of the anti-corruption agenda is often even more apparent. When national governments are weak and divided, and often do not have legitimacy with all parts of the population, the principle of national ownership in reality often means that one has to choose which factions to support and which ones not to support. Moreover, incumbent governments can have benefited from corruption to obtain power and may intend to use similar strategies to stay in power. It might therefore not be in the interest of such governments to fight corruption within their own ranks. Anti-corruption efforts can therefore become selective, so that only opposition members or people outside the incumbent ethnic group are targeted, or a windowdressing exercise altogether. 
The potential contradictions between the national ownership principle and the anti-corruption agenda relate to the mutual accountability principle. For the first time, the duties and responsibilities of donors were spelled out in the Paris Declaration: provide information on aid flows so recipient governments can improve their budgeting, and participate in joint assessments of mutual progress on agreed commitments. However, for corruption issues the concept of mutual accountability has also come to focus on aid as a driver of corruption (and the responsibility of aid agencies to counter this issue) as well as on aid agencies' responses to corruption cases (Hechler and Tostensen 2012, 4-21).

In acknowledgement of the special difficulties for anti-corruption work, the OECD has established a set of principles that provide some counterweight to the Paris Declaration. These 'Principles for Donor Action in Anti-corruption' state that (1) developing countries are expected to combat corruption via international conventions such as the UNCAC and the recommendations of the Financial Action Task Force (FATF) on anti-money laundering; (2) developed countries should respond better to the supply side of corruption; and (3) existing knowledge on anti-corruption should be better systematised and analysed to develop lessons learned (OECD 2013). Principle one allows donors to remind the recipient governments about their international responsibilities under the mutual accountability principle. Principle two relates to domestic accountability and may conflict with the national ownership principle. The third principle again relates to mutual accountability, but here on the side of aid agencies.

The 'New Deal for Engagement in Fragile States' builds on the principles of previous aid effectiveness policies, but focuses specifically on fragile states. The policy provides a framework in which donors and host countries establish shared priorities for reducing fragility. Ownership, harmonisation, alignment, managing for results and mutual accountability are considered no less important, but the Paris Declaration and Accra Agenda were not considered to have prompted the necessary changes in the way aid agencies work in fragile states:

International partners can often bypass national interests and actors, providing aid in overly technocratic ways that underestimate the importance of harmonising with the national and local context, and support short-term results at the expense of medium- to long-term sustainable results brought about by building capacity and systems. A New Deal for engagement in fragile states is necessary. (OECD 2011,1) 
The New Deal agreement establishes Peacebuilding and Statebuilding Goals (PSGs) to function as the guiding star rather than the Millennium Development Goals. The five PSGs are:

- legitimate politics: foster inclusive political settlements and conflict resolution

- security: establish and strengthen people's security

- justice: address injustices and increase people's access to justice

- economic foundations: generate employment and improve livelihoods

- revenues and services: manage revenue and build capacity for accountable and fair service delivery.

Aid organisations commit to using these PSGs to guide their aid priorities and funding decisions at the country level, to break the status quo and ensure that aid work in fragile states is no longer business as usual (OECD 2011, 2). The main challenge for the New Deal is to go beyond technical responses to politically smart engagement. The policy provides more space for political dialogue than the Paris Declaration, but aid agencies need to develop their own operational guidelines on how to develop programming and link technical and diplomatic responses to corruption concerns in fragile states. So far, the potential of the policy for improving control of corruption remains largely unfulfilled (Zaum et al. 2015).

\subsubsection{Do No Harm and Zero Tolerance}

A key principle for any stabilising anti-corruption intervention is not to do harm. Michael Johnston's (2010) background paper to the World Development Report 2011 first provided this important message. The title of the paper: 'First, do no harm - then, build trust' captures the essence. Do no harm means:

avoiding premature or poorly-thought-out reforms that can do more harm than good - notably, steps that overwhelm a society's capacity to absorb aid and put it to effective use, and that risk pushing fragile situations and societies into particular kinds of corruption that are severely disruptive. (Johnston 2010, 1)

Efforts to control corruption can do harm if they overwhelm a society's capacity to absorb aid, if they are captured to damage rivals or if they obstruct the peace-building process. There are indications that this seemingly simple message has not been properly understood by aid 
agencies. They may still do the wrong things for the right reasons. A survey of primarily bilateral aid agency staff shows that agencies give priority to minimising their own fiduciary risk, which is a skewed and narrow understanding of the do no harm principle. Policy and practice need to be much better aligned (Johnston and Johnsøn 2014).

Some anti-corruption reforms, such as the establishment of anticorruption authorities, can be harmful if they are used to target political opponents. Corruption in aid operations is of course not only harmful to society but also to aid agencies themselves. This is most likely why many agencies focus most of their efforts on protecting their own funds. Chapter 4 on Afghanistan presents several examples of the damage that corruption in aid agencies does to development efforts.

Another important principle for aid agencies engaged in anticorruption activities is zero tolerance. Stringent zero-tolerance policies are useful as a way to signal toughness, but can be operationally meaningless in a fragile state context where corruption is systemic. Aid agencies regard all forms of corruption as universally damaging. The causal relationship between corruption and poverty prevailing in today's view is well captured by former UN Secretary General Kofi Annan in a speech at the UN General Assembly on the adoption of the UNCAC in 2003:

Corruption is an insidious plague, that has a wide range of corrosive effects on societies. It undermines democracy and the rule of law, leads to violations of human rights, distorts markets, erodes the quality of life, and allows organised crime, terrorism, and other threats to human security to flourish. (Annan 2003: n.p.)

The view of corruption as a cancer may have been useful in getting the anti-corruption agenda accepted and defined in the mid-1990s, but the campaign rhetoric used in 'fighting' corruption also has some adverse effects when rhetoric has to be translated into policy and practice, and can be at odds with the aid effectiveness agenda discussed above, particularly for fragile states.

Stringent zero-tolerance policies are useful for aid organisations as they can easily be communicated to the domestic constituency, signalling toughness, but are often not founded on clear rational deliberations (Trivunovic et al. 2011, 16). Hard-line zero-tolerance policies present inverse incentives for whistle blowers and can therefore lead to less effective corruption controls (Lambsdorff 2007, 226). NGOs also regularly complain that aid agencies stop funding useful activities on the basis of mere suspicions of corruption. 
The view that any type of corruption should be fought can seem both unrealistic and ideological in a fragile state context. This may contribute to aid agencies retrenching from the aid effectiveness agenda, bypassing government systems because they believe they have more control over funds using their own systems. This is not always the case. The Afghan public financial management system is judged by many experts as less risky than those of most aid agencies. Yet, many agencies still insist on using their own procurement systems. Perhaps the most damaging effect of a rigid zero-tolerance approach in fragile states is that international actors are overwhelmed and end up doing nothing about corruption in the early phases of the intervention. The argument that one has to reach a certain level of state building before one can fight corruption is nonsense, but convenient. The question of corruption is set aside until it has become so entrenched that it demands action. Paradoxically, a poorly operationalised zero-tolerance policy can end up doing more harm than good.

\subsubsection{Stabilising Anti-corruption Interventions: Consider Capability and Time}

Aid agencies have recognised the need to reformulate their objectives and change their working methods for fragile states in their own organisational strategies and in high-level policy frameworks such as the New Deal. Development support in fragile contexts can no longer be business as usual (European Council 2006b, 5; World Bank 2011a, xii; UNDP 2012a, 11). However, specific guidance on how efforts to reduce corruption in fragile states should change is hard to find for staff working within these agencies. What is a stabilising anti-corruption reform that will work in a fragile state?

The next chapter presents the theory behind why and how anticorruption efforts need to change. This section shows a conceptual model that builds on the theory below and illustrates how one can view governance and anti-corruption interventions in relation to two factors of importance for aid agencies' working modalities: (a) the timing of the intervention, and (b) the capability ${ }^{11}$ to formulate and implement policies in the recipient administrative structures (government or civil society). The circles in Figure 1.1 represent the span of the interventions relating to the axes of time and capability.

Emergency humanitarian assistance is normally the earliest intervention in fragile states when the level of capability in the country is very low. Circle A represents these interventions. Anti-corruption efforts for such immediate assistance typically focus on protecting own funds amidst substantial corruption risks, not on strengthening country systems 
to promote stability (Bailey 2008). Later, often much later, aid agencies begin to work on helping institutions in the country to curb corruption. Such anti-corruption reforms have traditionally been implemented in contexts with higher capability levels (c1) and after a longer time span (t1) than that which characterises emergency humanitarian work. These types of traditional aid interventions fall under the 'good governance' span of activities and are represented by circle C. However, for work in fragile states there is a need for aid agencies to choose interventions that require less capability (c2) and that can be initiated earlier (t2), as emphasised by the WDR 2011 (World Bank 2011a, 13). This new type of activity to curb corruption is called stabilising anti-corruption reforms in this book. Stabilising interventions are earlier interventions with less reliance on government/civil society capability than good governance interventions. Circle B shows that stabilising interventions occupy a space between emergency humanitarian assistance and good governance interventions that is currently not filled.

Stabilising interventions happen in the short to intermediate term. Please note that 'intermediate' is meant as a much longer period than that considered by most development programming today. Generally, aid agencies operate within an assumption that a positive result in terms of reducing corruption can be achieved with relatively few financial resources over a relatively short period of time (Johnsøn 2012, 39). However, the World Development Report 2011 documents that the 20 fastest-moving countries needed an average of 27 years to bring corruption under reasonable control (World Bank 2011a, 108).

Due to special characteristics, such as the conflict trap, many fragile states are prone to lapse back into violence, civil war and disintegration (Collier 2008, 27). Even for the most successful countries, it has typically taken more than a generation to break the vicious circle of poverty and conflict (World Bank 2011a, 108). This would suggest that aid agencies need longer and more coherent engagements and that assistance in the short to intermediate term should be oriented towards stabilising interventions that can help reduce fragility. The time lag before commencement of anti-corruption activities, waiting for $\mathrm{c} 1$, can have detrimental effects as corrupt patterns can become deeply rooted in society.

Another pivotal difference between conventional good governance activities and stabilising interventions is the increased need to coordinate development, political and security actors in fragile contexts, and design interventions to work with the local context and politics. This is not captured in Figure 1.1, but discussed throughout the rest of the book. The recent emphasis on flexible programming and the need to think and act politically are essential for effective anti-corruption work in fragile states. 
Scholarship by, for example, Pritchett, Woolcock and Andrews (2010) and Andrews (2013) suggests that approaches to aid delivery should be problem-driven, iterative and adaptive. Such approaches would clearly reduce many implementation challenges. However, they have proven difficult for aid agencies to apply. Aid agencies are conscious that politics matters for state building and development, yet serious barriers to political engagement remain (Unsworth 2009). Calls for 'politically smart, locally led' approaches have not yet been translated to the area of interest for this study, but are generally consistent with the finding that technical fixes rarely work in isolation (Booth and Unsworth 2014).

A shift in focus from stabilising interventions (safeguarding human security and wellbeing and reducing risks of conflict) to good governance (to achieve economic and/or human development) would happen as institutions become more resilient to stresses and the context is no longer marked by fragility.

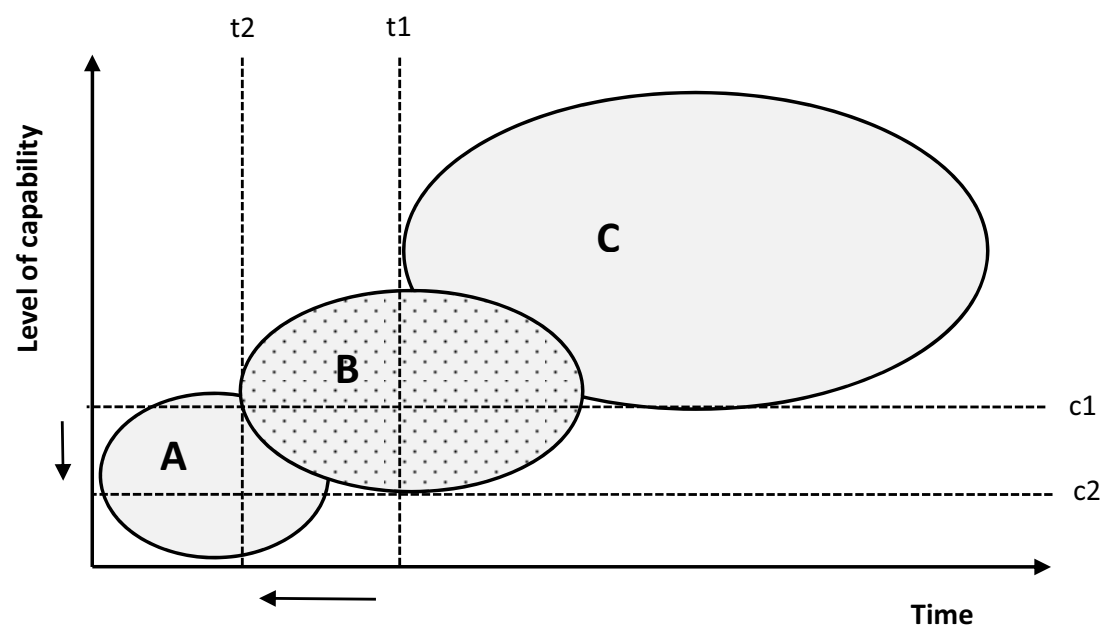

Figure 1.1 Stabilising interventions: differences in relation to time and capability

The most common anti-corruption reforms used by aid agencies were originally conceptualised to promote good governance, not to reduce fragility. Such good governance interventions normally target petty forms of corruption, often at the point of front-line service delivery. Other types of corruption may matter more for stability. The majority of the good governance interventions would require a rethink to be feasible to 
implement as earlier interventions in contexts where recipient administrative structures have lower capability.

\subsection{SUMMARY}

Corruption is an act that undermines institutional structures that promote a shared public interest. It distorts politics, the political system and shared norms for governance and public accountability. The dominant definitions used in academia and the aid community are public office centred definitions, without reference to public interest or politics. This is problematic, particularly in fragile states. Conceptions of corruption that incorporate the notion of the public interest bring important insights to anti-corruption efforts in fragile states with no Weberian concept of public office and weak governance structures.

Corruption is an elusive concept for a range of more specific manifestations. Some categories and patterns of corruption can have greater relevance for efforts to reduce fragility. An exclusive focus on petty and bureaucratic corruption may matter little for political accountability, the legitimacy of the state, the potential for future conflict, and thereby stability. Patronage and clientelism can have different manifestations and therefore be either stabilising or destabilising, depending on the context.

Aid agencies distinguish between direct and indirect anti-corruption projects, prioritising the latter with mainstreaming as the overarching strategy. A standard set of anti-corruption actions and approaches are found to be at the agencies' disposal. The rest of the study will analyse whether they are all appropriate for use in fragile states or whether a differentiated strategy is needed.

Fragility is not a measure of low stages of development in a country. The defining challenges of fragile states relate to crisis, conflict and other forms of vulnerability. However, the formal definitions of the World Bank and the EU focus on a country's performance in terms of traditional development outcomes, that is, good governance outcomes. Aid agencies should develop, restore or strengthen policies and institutions that promote the legitimacy of shared governance structures, safeguard human security and wellbeing, and reduce the risk of conflict. The aim is to have resilient institutions that can weather the storms.

The concept of state building often implicitly has a goal of promoting good governance and building up state institutions. Good governance is the development objective to which most anti-corruption activities traditionally have been expected to contribute. After all, corruption is seen as the ultimate symptom of bad governance. Aid agencies agree that 
governments need to account for how economic and social resources are managed in an effective and equitable way, but disagree about how far beyond good administration of a country's resources the concept of good governance is meant to go - that is, the extent to which civic participation, democracy and human rights are an integral part of governance. There is, however, general agreement between agencies that capacity and institution building is the way to promote good governance.

This study shows that the aim should be good-enough inclusive governance in fragile states. Traditional anti-corruption reforms, aimed at building good governance, are at best ineffective and at worst harmful. Anti-corruption interventions should be stabilising and not do harm. This is not a call for inaction. Sometimes doing nothing about corruption can be very harmful. Effective anti-corruption activities will target the types of corruption that matter for fragility. This requires good diagnostics of the drivers of corruption. Finally, efforts to curb corruption in fragile states will work best if they are initiated early and are designed so that they do not overload those organisations in charge of the implementation of the reforms.

\section{NOTES}

1. The definition of political science as the study of 'who gets what, when, how?' can be traced back to Lasswell's seminal book titled Politics: Who gets what, when, how (1936).

2. Hellman, Jones and Kaufmann $(2000$, i) were concerned with how firms and oligarchs could 'shape the policy making, regulatory and legal environments to their own advantage, generating concentrated rents at the expense of the rest of the economy' via bribery. However, the term 'state capture' has evolved since then and is now also frequently used to characterise situations where actors that are not firms take control of the state apparatus to extract rents.

3. See also Johnston (2013) for more cases and the argument that deep democratisation is the best antidote to corruption.

4. The countries are the USA, Germany (Prussia), Great Britain, France, Japan, Spain, Brazil, Mexico, Chile and Argentina.

5. Bangladesh, India, Malaysia, Pakistan, Thailand and South Korea.

6. These distinctions were first made in a paper commissioned by DFID, and later published by U4, and during that process refinements were made based on discussions with Nils Taxell, Dominik Zaum and Phil Mason (Johnsøn et al. 2012, 2).

7. See the White Paper on European Governance (European Commission 2001).

8. Cheng and Zaum (2012a) have edited an informative book on corruption in post-conflict countries.

9. The most recent list is from the financial year 2015 (World Bank 2016a). However, in Chapter 3 the comparisons are done on the basis of the list from the financial year 2013 as this contains the countries that would have been considered fragile at the time in which country strategies were being developed (World Bank 2012f).

10. The cross-country fragility indices that are covered in the publication are the Bertelsmann Transformation Index - State Weakness Index; Country Indicators for Foreign Policy Fragility Index; Country Policy and Institutional Assessment (CPIA); Failed States Index; 
Global Peace Index; Harvard Kennedy School Index of African Governance; Index of State Weakness in the Developing World; Peace and Conflict Instability Ledger; Political Instability Index; State Fragility Index; and World Governance Indicators, Political Stability and Absence of Violence (DIE and UNDP 2009, 2).

11. Capability is defined in line with the WDR 1997 , as the ability to undertake and promote collective actions efficiently. The notion of capability encompasses the administrative or technical capacity of staff, but is broader than capacity by including the institutional mechanisms that give politicians and civil servants the ability to transform capacity into action (World Bank 1997c, 3, 77). 